\title{
MAKALAH LOMPAT JAUH
}

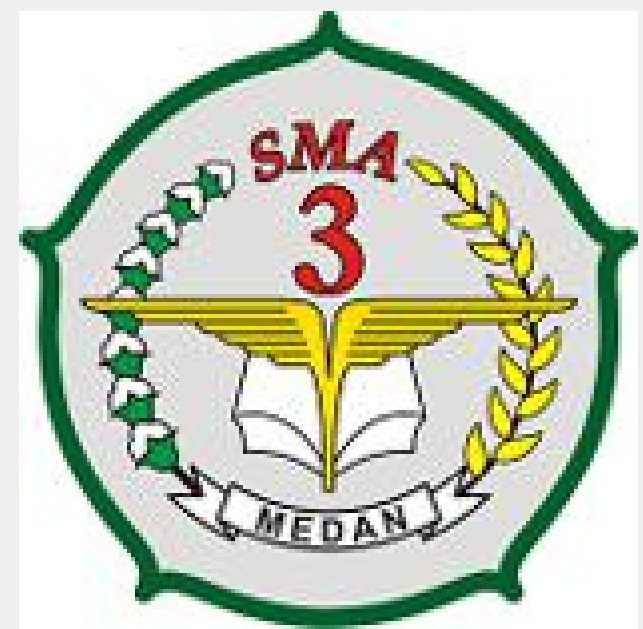

NAMA : RAUDHA FASHLI NUGRAHA KELAS : X MIA 1

TAHUN AJARAN : 2019/2020 


\section{KATA PENGANTAR}

Assalamualaikum Wr. Wb

Dengan memanjatkan puji syukur kehadirat Allah SWT atas limpahan rahmat serta hidayahnya, maka kami dapat menyelesaikan makalah ini dengan judul " Olahraga lompat jauh “

Semoga sholawat dan salam senantiasa tercurah limpahkan kepada Baginda Nabi Muhammad SAW, Keluarga, Sahabat dan para pengikutnya hingga akhir zaman. Amien ... !!!!

Penulis sangat menyadari bahwa makalah ini masih banyak kekurangan dan jauh dari kesempurnaan. Untuk itu kritik dan saran dari semua pihak sangat kami harapkan dami kesempurnaan makalah ini.

Wassalamualaikum Wr.Wb 


\section{BAB I \\ PENDAHULUAN}

\section{A. Latar Belakang}

Dalam kehidupan modern manusia tidak dapat dipisahkan dari olahraga, baik sebagai arena adu prestasi maupun sebagai kebutuhan untuk menjaga kondisi tubuh agar tetap sehat. Olahraga mempunyai peranan yang penting dalam kehidupan manusia. Melalui olahraga dapat dibentuk manusia yang sehat jasmani, rohani serta mempunyai kepribadian, disiplin, sportifitas yang tinggi sehingga pada akhirnya akan terbentuk manusia yang berkualitas. Suatu kenyataan yang bisa diamati dalam dunia olahraga, menunjukkan kecenderungan adanya peningkatan prestasi olahraga yang pesat dari waktu kewaktu baik ditingkat daerah, nasional maupun internasional. Hal ini dapat dilihat dari pemecahan-pemecahan rekor yang terus dilakukan pada cabang olahraga tertentu, penampilan tehnik yang efektif dan efisien dengan ditunjang oleh kondisi fisik yang baik.

\section{B. Rumusan Maslah}

1. Apa yang dimsud dengan lompat jauh ?

2. Bagaimanakah teknik lompatan ?

3. Bagaimanakah latihan lompat dan prinsip-psrinsip latihan?

4. Apasajakah macam-macam gaya lompat jauh ?

5. Bagaimanakah lapangan lompat jauh ?

6. Bagaimanakah Peraturan permainan lompat jauh ? 


\section{BAB II \\ PEMBAHASAN}

\section{A. Lompat Jauh}

Lompat jauh merupakan salah satu nomor lompat dari cabang olahraga atletik. Lompat jauh menurut Aip Syarifuddin (1992 : 90) didefinisikan sebagai suatu bentuk gerakan melompat, mengangkat kaki keatas kedepan dalam upaya membawa titik berat badan selama mungkin diudara (melayang diudara) yang dilakukan dengan cepat dan dengan jalan melakukan tolakan pada satu kaki untuk mencapai jarak yang sejauh-jauhnya.

Lompat jauh merupakan suatu gerakan melompat menggunakan tumpuan satu kaki untuk mencapai jarak sejauh-jauhnya. Sasaran dan tujuan lompat jauh adalah untuk mencapai jarak lompatan sejauh mungkin kesebuah letak pendaratan atau bak lompat. Jarak lompatan diukur dari papan tolakan sampai batas terdekat dari letak pendaratan yang dihasilkan oleh bagian tubuh.

\section{B. Teknik Lompat Jauh}

Lompat jauh mempunyai empat fase gerakan, yaitu awalan, tolak an, melayang dan mendarat serta terdapat tiga macam gaya yang membedakan antara gaya yang satu dengan gaya yang lainnya pada saat melayang diudara. Uraian mengenai keempat fase gerakan dalam lompat jauh adalah sebagai berikut:

a. Awalan

Awalan adalah langkah utama yang diperlukan oleh pelompat untuk memperoleh kecepatan pada waktu akan melompat. Seperti dikatakan Aip Syarifuddin (1992 : 90) awalan merupakan gerakan permulaan dalam bentuk lari untuk mendapatkan kecepatan pada waktu akan melakukan tolakan (lompatan). Jarak awalan yang biasa dan umum digunakan oleh para pelompat (atlet) dalam perlombaan lompat jauh 
adalah : 1) untuk putra antara $40 \mathrm{~m}$ sampai $50 \mathrm{~m}$; 2) untuk putri antara 30 m sampai dengan $45 \mathrm{~m}$.

b. Tumpuan atau Tolakan

Tumpuan atau tolakan adalah gerakan menolak sekuat-kuatnya dengan kaki yang terkuat, yaitu meneruskan kecepatan horizontal ke kekuatan vertical yang dilakukan secara cepat. Menurut Engkos Kosasih (1985 : 67) tolakan yaitu menolak sekuat-kuatnya pada papan tolakan dengan kaki terkuat ke atas (tinggi dan ke depan). Dengan demikian dapatlah dikatakan bahwa melakukan tolakan berarti jarak merubah kecepatan horizontal menjadi kecepatan vertical.

c. Melayang di Udara

Sikap melayang adalah sikap setelah gerakan lompatan dilakukan dan badan sudah terangkat tinggi keatas. Menurut Aip Syarifuddin (1992 : 92/93) sikap dan gerakan badan di udara sangat erat hubungannya dengan kecepatan awalan dan kekuatan tolakan. Karena pada waktu pelompat lepas dari papan tolakan badan si pelompat akan dipengaruhi oleh suatu kekuatan yaitu gaya gravitasi (gaya penarik bumi).

Untuk itu, kecepatan lari awalan dan kekuatan pada waktu menolak harus dilakukan oleh pelompat untuk mengetahui daya tarik bumi tersebut. Dengan demikian jelas bahwa pada nomor lompat jauh kecepatan dan kekuatan sangat besar pengaruhnya terhadap hasil tolakan.

d. Mendarat

Mendarat adalah sikap jatuh dengan posisi kedua kaki menyentuh tanah secara bersama-sama dengan lutut dibengkokkan dan mengeper sehingga memungkinkan jatuhnya badan kearah depan. Seperti dikatakan Yusuf Adisasmita (1992 : 68) pada saat mendarat titik berat badan harus dibawa kemuka dengan jalan membungkukkan badan hingga lutut hampir merapat, dibantu pula dengan juluran tangan kemuka.

\section{Latihan Lompat dan Prinsip-Prinsip Latihan}

a. Pengertian Latihan Lompat 
Latihan adalah proses yang sistematis daripada berlatih atau bekerja secara berulang-ulang dengan kian hari kian menambah jumlah beban latihan atau pekerjaannya (Harsono, 1982 : 27). Lompat adalah istilah yang digunakan dalam cabang olahraga atletik, yaitu melakukan tolakan dengan satu kaki, Aip Syarifuddin (1992 : 90). Pengertian latihan lompat dari pendapat tersebut dapat disimpulkan yaitu melakukan gerakan melompat dengan tumpuan satu kaki yang dilakukan secara berulang-ulang dan setiap hari jumlah beban latihan ditambah.

b. Prinsip-Prinsip Latihan

1. Prinsip Latihan Beban Bertambah ( Overload )

Untuk meningkatkan prestasi atlit prinsip overload harus digunakan. Apabila atlet sudah merasa ringan pada beban yang diberikan maka beban harus ditambah. Menurut M. Sajoto (1988 : 42) dengan berprinsip pada overload, maka kelompok-kelompok otot akan bergabung kekuatannya secara efektif dan akan merangsang penyesuaian fisiologis dalam tubuh yang mendorong meningkatkan kekuatan otot.

2. Prinsip Peningkatan Beban Terus Menerus

Otot yang menerima beban latihan lebih atau overload kekuatannya akan bertambah dan apabila kekuatan bertambah, maka program latihan berikutnya bila tidak ada penambahan beban, tidak lagi dapat menambah kekuatan. Penambahan beban dalam jumlah repetisi tertentu, otot belum merasakan lelah. Prinsip penambahan beban demikian dinamakan prinsip penambahan beban secara progresif. (M. Sajoto, 1988 : 115).

3. Prinsip Urutan Pengaturan Suatu Latihan

Latihan berbeban hendaknya diatur sedemikian rupa sehingga kelompok otot besar mendapat giliran latihan lebih dulu sebelum latihan otot kecil. Hal ini perlu agar kelompok otot kecil tidak mengalami kelelahan terlebih dahuu, sebelum kelompok otot mendapat giliran latihan pengaturan latihan hendaknya diprogramkan 
sedemikian rupa sehingga tidak terjadi dua bagian otot dalam tubuh yang sama mendapat dua giliran latihan secara berurutan (M. Sajoto, $1988: 115)$

4. Prinsip Kekhususan Program Latihan

Menurut O'shea dalam bukunya M. Sajoto (1988: 42) menyatakan bahwa semua program latihan harus berdasarkan "SAID" yaitu Specific Adaptation to Imposed Demands. Prinsip tersebut menyatakan bahwa latihan hendaknya bersifat khusus, sesuai dengan sasaran yang akan dicapai.

\section{Macam-macam gaya lompat jauh}

\section{a. Lompat Jauh Gaya Jongkok (Gaya Orthodok)}

1. antara 30 sampai 40 meter. Latihan kecepatan awalan dapat dilakukan dengan latihan-latihansprint $10-20$ meter yang di lakukan berulang-ulang. Panjang langkah, jumlah langkah, dan kecepatan berlari dalam mengambil awalan harus selalu sama. Menjelang tiga sampai empat langkah sebelum balok tumpu, seorang pelompat harus dapat berkonsentrasi untuk dapatmelakukan tumpuan dengan kuat. Dengan catatan tanpa mengurangi kecepatan.

2. Tumpuan atau tolakan adalah perpindahan yang sangat cepat antara lari awalan dan melayang. Ketepatan tumpuan pada balok tumpu serta besarnya tenaga tolakan yangdihasilkan oleh kaki (explosive power) kaki sangatlah menentukan pencapaian hasil lompatan. Oleh sebab itu, latihan ketepatan menumpu pada balok tumpu dapat dilakukandengan jumlah langkah sebanyak 5 hingga 7 langkah. Tumpuan kaki dapat di lakukan dengankaki kiri maupun kaki kanan tergantung dari kaki mana yang lebih kuat dan lebih dominan.Pada waktu menumpu badan condong ke depan, titik berat badan harus terletak agak kedepan, titik berat badan harus terletak agak ke depan. Titik sumber tenaga, yaitu kaki tumpumenumpu secara tepat pada balok tumpu, segera diikuti dengan gerakan kaki ayunkan kearah depan atas. Dengan sudut tolakan berkisar antara $40-50$ derajat. 
3. Melayang (sikap badan saat di udara) adalah setelah pelompat menumpu pada balok tumpuan, maka dengan posisi badan condong ke depan terangkat melayang di udara,bersamaan dengan ayunan kedua lengan ke depan atas. Untuk mendapatkan tinggi dan jauhnya lompatan harus meluruskan kaki tumpu selurus-lurusnya dan secepat-cepatnya. Padawaktu naik, badan harus dapat ditahan dalam keadaan rileks (tidak kaku) kemudianmelakukan gerakan-gerakan sikap tubuh di udara (waktu melayang) inilah biasanya yang disebut gaya lompatan dalam lompat jauh. Pada waktu di udara dengan sikap jongkok saat kakitolak menolakkan kaki pada balok tumpuan, kaki diayunkan ke depan atas untuk membantumengangkat titik berat badan ke atas kemudian diikuti kaki tolak menyusul kaki ayun. Saatmelayang ke dua kaki sedikit di tekuk sehingga posisi badan berada dalam sikap jongkok.Keadaan ini supaya dapat dipertahankan sebelum melakukan pendaratan.

4. Mendarat adalah pada waktu mendarat pelompat harus menjulurkan kedua belah tangansejauh-jauhnya ke muka dengan tidak kehilangan keseimbangan badannya supaya tidak jatuhke belakang. Untuk mencegahnya berat badan harus di bawa ke depan dengan caramembungkukkan badan dan lutut hampir merapat dibantu dengan cara menjulurkan tangankedepan. Pada waktu pendaratan lutut dibengkokan sehingga memungkinkan suatu momentum membawa badan ke depan atas kaki mendarat di lakukan dengan tumit terlebihdahulu mengenai tanah.

\section{b. Lompat Jauh Gaya Menggantung (Gaya Schnepper)}

Gaya menggantung merupakan salah satu gaya dalam lompat jauh. Mengapa di sebutgaya menggantung, karena gerak dan sikap badan di udara menyerupai dengan orang yangsedang menggantung atau melenting ke belakang. Yang harus dikuasai unsur-unsur dalammelakukan lompat jauh gaya menggantung adalah; awalan, tumpuan/tolakan, melayang danmendarat. Tanpa penguasaan teknik yang baik dan benar hasil yang diperolehnya tidak akanmaksimal. 
a. Awalan adalah gerak awal yang dimulai dengan lari, ini berguna untuk mendapatkankecepatan lari setinggi-tingginya sebelum mencapai balok tumpuan. Jarak awalan lari,tergantung pada tiap-tiap pelompat. Bagi para pemula mengambil awalan cukup 20 sampai25 meter, tetapi bagi atlet yang sudah mapan, untuk membangun kecepatan maksimum harusmengambil awalan antara 30 sampai 40 meter.

b. Tumpuan/tolakan merupakan perpindahan yang cepat antara lari, awalan dan melayang.Urutan melakukan tumpuan yang benar adalah:

Tolakan dengan salah satu kaki yang lebih kuat dan dominan.

Ketepatan tumpuan pada balok tumpu serta tenaga tolakan sangat menentukan hasillompatan.

Pada saat kaki menumpu pada balok, badan harus agak condong ke depan.

Titik berat badan harus terletek agak ke muka.

Gerakan kaki ayun ke arah depan atas.

Sudut tolakan kurang lebih 45 derajat.

c. Melayang (sikap badan saat di udara) adalah pelompat menumpu pada balok tumpuan, makabadan akan dapat terangkat di udara dengan sikap/gaya menggantung untuk melakukannya.

Pada saat melayang kaki diayun dan diangkat ke depan.

Kaki tolak selepas dari tanah diayunkan kembali ke belakang bersamaan atau sejajardengan kaki ayun.

Sikap badan dibusungkan ke depan atau melenting ke belakang.

Lengan diayunkan ke atas belakang.

Kepala tengadah.

d. Mendarat adalah pada waktu mendarat pelompat harus berusaha menjulurkan kedua belahtangannya. Sejauh-jauhnya kemuka serta tidak kehilangan keseimbangan badannya. Pada saatini biasanya timbul perasaan, badan akan jatuh ke belakang, untuk mencegahnya titik beratharus di bawa ke depan dengan jalan membungkukan badan, hingga badan dan lutut hampirmerapat, dibantu pula dengan juluran 
tangan ke muka. Pada waktu pendaratan lututdibengkokan sehingga memungkinkan suatu momentum membawa ke depan atas, kakimendarat dilakukan dengan tumit terlebih dahulu mengenai tanah.

\section{c. Lompat Jauh Gaya Berjalan di Udara (Walking in the Air)Gaya berjalan di udara}

a. merupakan salah satu gaya dalam lompat jauh. Mengapa di sebutgaya berjalan di udara, karena gerak dan sikap badan di udara menyerupai dengan orang yang sedang berjalan. Yang harus dikuasai unsur-unsur dalam melakukan lompat jauh gaya berjalan diudara adalah; awalan, tumpuan/tolakan, melayang dan mendarat. Tanpa penguasaan teknik yang baik dan benar hasil yang diperolehnya tidak akan maksimal.

1. Awalan adalah saat melakukan awalan sebaiknya dilakukan pada jarak yang dirasakan cukupmemadai oleh pelompat. Pelompat memiliki naluri yang berbeda antara pelompat yang satudengan yang lainnya. Yang perlu dipahami oleh seorang pelompat jauh adalahpengembangan akselerasi, distribusi energi, dan kecepatan. Agar saat tolakan tepat, guru bisamenggunakan tanda pada lintasan yang akan dilalui pelompat.

2. Tumpuan adalah saat melakukan tumpuan dapat digunakan kaki kiri atau kanan sesuaidengan kebiasaan pelompat. Sebaiknya gunakan kaki yang memiliki kekuatan dominan.Ketika kaki menumpu ke balok badan harus dicondongkan ke depan agar keseimbangan tetapterjaga. Pandangan ke depan dengan kedua lengan berada di samping atas badan.

3. Melayang adalah setelah pelompat menumpu pada balok tumpuan, maka badan akan dapatterangkat ke udara. Dengan melakukan sikap berjalan di udara kedua kaki saling bergantian mengayuh di udara. Sebelum kaki mendarat upayakan berada dalam posisi di udara selama mungkin, agar menghasilkan lompatan maksimal.

4. Mendarat adalah pada waktu mendarat pelompat harus berusaha menjulurkan kedua belahtangannya ke depan dan kemudian ditarik 
ke belakang. Sementara kedua kaki dilujurkan ke depan sejauh mungkin. Daratkan kedua kaki secara bersamaan agar terhindar dari cedera.Jatuhkan berat badan ke depan.

\section{E. Lapangan lompat jauh}

\section{a. Catatan}

Bak lompat diisi dengan pasir

Apabila pelompat gagal/diskualifikasi yuri mengangkat bendera merah

Apabila pelompat melakukan dengan baik yuri mengangkat bendera putih

Lebar awalan $122 \mathrm{~cm}$

Panjang balok $122 \mathrm{~cm}$

Lebar balok $20 \mathrm{~cm}$

b. Hal-hal yang perlu dihindari :

Memperpendek atau memperpanjang langkah terakhir sebelum bertolak.

- $\quad$ Bertolak dari tumit dengan kecepatan yang tidak memadai.

- $\quad$ Badan miring jauh kedepan atau kebelakang.

- $\quad$ Fase yang tidak seimbang.

- $\quad$ Gerak kaki yang premature.

- Tak cukup angkatan kaki pada pendaratan.

- $\quad$ Satu kaki turun mendahului kaki lain pada darat.

\section{c. Hal - hal yang harus diperhatikan/dilakukan}

pelihara kecepatan sampai saat menolak

capailah dorongan yang cepat dan dinamis dan balok tumpuan.

Rubahlah sedikit posisi lari, baertujuan mencapai posisi lebih tegak.

- $\quad$ Gunakan gerakan kompensasi lengan yang baik

- $\quad$ Capailah jangkuan gerak yang baik.

- $\quad$ Gerak akhir agar dibuwat lebih kuat dengan menggunakan lebih besar daya kepadanya. 
- Latihan gerakan pendaratan.

- $\quad$ Kuasai gerak yang betul dari lengan dan kaki dalam meluruakan dan membengkokkan.

\section{F. Peraturan permainan lompat jauh}

1. Hal hal yang perlu diperhatikan untuk meraih hasil maksimal

- Jarak awalan 30-40 dan dilakukan secepat cepatnya

- $\quad$ Menggunakan kaki yang kuat untuk melakukan tolakan.

- $\quad$ Diusahakan melayang selama mungkin

- $\quad$ Waktu mendarat jangan sampai jatuh ke belakang

\section{Diskualifikasi}

- $\quad$ Dipanggil 3 menit belum melompatMenumpu dengan 2 kaki

- Kembali ke arah awalan, setelah melompat

- Mendarat luar bak lompat

- Juri mengangkat bendera merah apabila pelompat gagal

- Juri mengangkat bendera putih jika lompatan benar 


\section{BAB III}

\section{PENUTUP}

\section{A. Kesimpulan}

Berdasakan hasil pembahasan di atas, maka dapat menyimpulkan bahwa :

1. Lompat jauh merupakan salah satu nomor lompat dari cabang olahraga atletik.

2. Lompat jauh mempunyai empat fase gerakan, yaitu awalan, tolakan, melayang dan mendarat serta terdapat tiga macam gaya yang membedakan antara gaya yang satu dengan gaya yang lainnya pada saat melayang diudara.

3. Adapun Prinsip Latihan adalah Beban Bertambah ( Overload), Prinsip Peningkatan Beban Terus Menerus, Prinsip Urutan Pengaturan Suatu Latihan, Prinsip Kekhususan Program Latihan.

\section{B. Saran}

Penulis banyak berharap para pembaca dapat memberikan kritik dan saran yang membangun kepada penulis demi sempurnanya makalah ini dan untuk penulisan makalah di kesempatan-kesempatan berikutnya. 


\section{DAFTAR PUSTAKA}

$\varnothing$ http://henirahma369.blogspot.com/2013/09/makalahtugas-penjaskes-lompatjauh.ht $\mathrm{ml}$ 